\title{
SAMBUCUS NIGRA В СКЛАДІ ФАРМАЦЕВТИЧНИХ ПРЕПАРАТІВ, ПРЕДСТАВЛЕНИХ НА РИНКУ УКРАЇНИ
}

\author{
Н. Є. Стадницька, О. М. Федоришин, А. О. Милянич, Х. І. Косаревич, \\ В. П. Новіков
}

Національний університет «Львівська політехніка», Львів

nataliyastadnytska@gmail.com

ІНФОРМАЦІЯ

Надійшла до редакції / Received: 21.02.2019

Після доопрацювання / Revised: 30.04.2019

Прийнято до друку / Accepted: 15.05.2019

\section{Ключові слова:}

бузина чорна Sambucus nigra; препарати на основі рослинної сировини;

маркетингове дослідження;

фрармацевтичний ринок України.
АНОТАЦІЯ

Мета роботи. Провести аналіз асортименту лікарських препаратів представлених на сучасному фармацевтичному ринку України, які містять у своєму складі бузину чорну Sambucus nigra, та на підставі одержаних результатів визначити доцільність розробки нових препаратів з її вмістом. Матеріали і методи. Аналіз асортименту препаратів проводили спираючись на дані Державного реєстру лікарських засобів України (станом на січень 2019 р.). Роботу виконано з використанням статистичного, логічного та грасрічного методів.

Результати й обговорення. Проведені дослідження показали, що найбільше лікарських засобів представлені у вигляді таблеток (26,4 \%); переважаючу частку асортименту (95 \%) досліджених препаратів складають багатокомпонентні лікарські засоби; більшість препаратів із вмістом бузини чорної Sambucus nigra вироблені на фрармацевтичних підприємствах України, серед яких лідером (55,56 \%) є ТОВ Науково-виробнича компанія «ЕЙМ», м. Харків; найчастіше лікарські препарати із вмістом бузини чорної - це протизапальні засоби. Отже, отримані результати вказують на те, що розробка нових сучасних оригінальних лікарських засобів на основі бузини чорної Sambucus nigra $€$ перспективною та конкурентоздатною на вітчизняному фрармацевтичному ринку.

Висновки. Проведений маркетинговий аналіз українського ринку лікарських та лікувально-профрілактичних препаратів показав, що хоча частка вітчизняних засобів на основі бузини чорної Sambucus nigra і найбільша, однак $€$ широкі можливості щодо розширення асортименту та створення нових препаратів на основі даної рослинної сировини. Зокрема варто звернути увагу на найменш численні (сиропи та розчини для ін'єкцій) або взагалі не представлені фрорми (спреї, пастилки та драже).
Вступ. На сьогодні лікарські рослини та лікарські засоби, що одержують з них, широко застосовують у медичній практиці й користуються великим попитом у населення. Номенклатура рослинних препаратів, за даними орахівців, у різних країнах складає 10-26 \% від загального об'єму лікарських засобів, що випускаються.
Такий попит на сучасні фрітопрепарати та тенденція до їх ширшого використання в медичній практиці не випадкові. Це пояснюється тим, що рослинні лікарські засоби мають ряд безперечних переваг. Вони широко застосовуються при комплексному лікуванні різних захворювань, відрізняються низькою токсич-

ISSN 2312-0967. Фармацевтичний часопис. 2019. № 2 
ністю, легким засвоєнням організмом людини, можливістю тривалого їх використання без ризику виникнення побічних явищ, м'якістю та надійністю дії $[1,2]$

Часто об'єктами наукових досліджень є лікарські засоби, що використовуються при лікуванні певних хвороб. Рідко аналізуються препарати із вмістом окремих рослин. Разом з цим, розширення спектра використання відомих лікарських рослин є одним із напрямків сучасних досліджень. Мета нашого дослідження - ознайомлення із зареєстрованими на ринку України препаратами, що містять у своєму складі витяжки з бузини чорної Sambucus nigra [3]. Бузина чорна - це популярна лікарська рослина 3 широким спектром дії, яка широко використовується як в народній, так і в науковій медицині. Лікарською рослинною сировиною бузини чорної є квітки, плоди, листя, кора [4]. Фармакологічні властивості орітопрепаратів залежать від того, з якої морфологічних частин цієї рослини вони виготовленні, а отже, від якісного та кількісного вмісту біологічно активних речовин. Квітки бузини входять до складу потогінних, пом'якшувальних і послаблювальних зборів. У народній медицині настій квіток і листя або відвар кори приймають при захворюваннях дихальних шляхів у вигляді полоскань та примочок при ангіні, запаленні ротової порожнини й горла, при хворобах вух і очей, запорі, геморої, як жовчогінний засіб, при подагрі, артриті, анемії, ожирінні, хронічних хворобах шкіри (зокрема, при псоріазі). Відвари коріння і кори використовують і при діабеті, хворобах нирок і набряках. Ванни 3 відвару коріння й квіток вважаються ефективним засобом при ревматоїдному й подагричному поліартриті. Свіжі ягоди споживають при ревматизмі і невралгіях. Плоди, мають виражену послаблювальну дію. Із сушених ягід готують киселі, які споживають як послаблювальний засіб. Настій сушених ягід сприяє кращому випорожненню кишечника, поліпшує жовчовиділення, посилює діурез [3, 4].

Мета роботи - провести аналіз асортименту лікарських препаратів, представлених на сучасному фрармацевтичному ринку України, які містять у своєму складі бузину чорну Sambucus nigra та на підставі одержаних результатів визначити доцільність розробки нових препаратів з її вмістом.

Матеріали і методи. Аналіз асортименту препаратів проводили спираючись на дані Державного реєстру лікарських засобів України (станом на січень 2019 р.) та кваліфрікаційну систему ATC (Anatomical Therapeutic Chemical classification system). Робота виконана 3 використанням статистичного, логічного та графрічного методів. Проведено маркетингові дослідження та проаналізовано асортиментну структуру препаратів на основі бузини чорної, які згідно зі ст. 9 Закону України «Про лікарські засоби» [5], дозволені до застосування в Україні після їх державної реєстрації. Державну реєстрацію здійснює МО3 України на підставі результатів експертизи реєстра- ційних матеріалів на лікарський препарат та контролю його якості, проведених Державним експертним центром МО3 України [5].

Результати й обговорення. На фрармацевтичному ринку України станом на січень 2019 р. зареєстровано 19 препаратів з вмістом Sambucus nigra (Amма краплі оральні, Атма таблетки, Бузини чорної квітки, Бронхофріт настоянка, Бронхофіт збір, Квайт, Ново-пасит (таблетки, розчин оральний), Нефроopim, Екстракт складний заспокійливий, Синупрет (краплі, таблетки, сироп), Урохолум, Синупрет фрорте, Kapdioopim, Гастрофрim, Неінфекційні алергени групи пилку рослин, Синупрет екстракт (таблетки) $[6,7]$.

На рисунку 1 наведено результати проведеного аналізу препаратів за фрармакологічною дією, узятих із Державного реєстру лікарських засобів України, що містять у своєму складі Sambucus nigra [7]. Більшість цих препаратів проявляє: протизапальну (34,8 \%), снодійно-седативну $(17,4 \%)$, протиалергічну (13\%), спазмолітину (8,7\%), урологічну та сечогінну дію (8,7 \%), а також кардіологічну, антимікробну, відхаркувальну дії та регулюють травлення (по $4,35 \%)[6,7]$.

Ряд препаратів (табл. 1) на основі витяжок з бузини чорної рекомендуються науковою медициною як протизапальні засоби при запаленні верхніх дихальних шляхів, грипі, бронхіті, ларингіті, ларинго-трахеїті, при лікуванні захворювань, які супроводжуються кашлем з утрудненим відходження мокротиння. Завдяки сечогінним властивостям препарати бузини чорної (див. табл. 1) ефективні при лікуванні хронічної ниркової недостатності, запальних захворюваннях нирок і сечовивідних шляхів, сечокам'яної та нирковокам'яної хвороби, при набряках, пов'язаних із захворюваннями серця і бронхолегеневої системи $[3,8,9,10]$.

Залежно від кількості рослинних компонентів у фрітозасобі їх поділяють на однокомпонентні та багатокомпонентні. Згідно з даними Державного реєстру лікарських засобів України [7], із 19 зареєстрованих лікарських засобів із вмістом бузини чорної, переважаючу частку асортименту (95 \%) складають багатокомпонентні (рис. 2). Це пояснює краща ефективність зборів порівняно з однокомпонентними препаратами. Декілька рослин посилюють дію інших завдяки синергічності дії. Тобто, дві або більше рослин разом чинять більший загальний вплив, ніж кожна 3 них окремо [8-10].

Серед однокомпонентних препаратів виявлено лише один препарат Бузини чорної квітки Sambuci nigrae flores, який випускає український виробник (ПрАТ «Ліктрави», м. Житомир).

Проаналізувавши країни-виробники, видно, що більшість препаратів із вмістом Sambucus nigra вироблені на фрармацевтичних підприємствах України $(47,4 \%)$ (рис. 3).

ISSN 2312-0967. Pharmaceutical review. 2019. № 2 
Фармацевтичний менеджмент, маркетинг та логістика

Pharmaceutical management, marketing and logistics

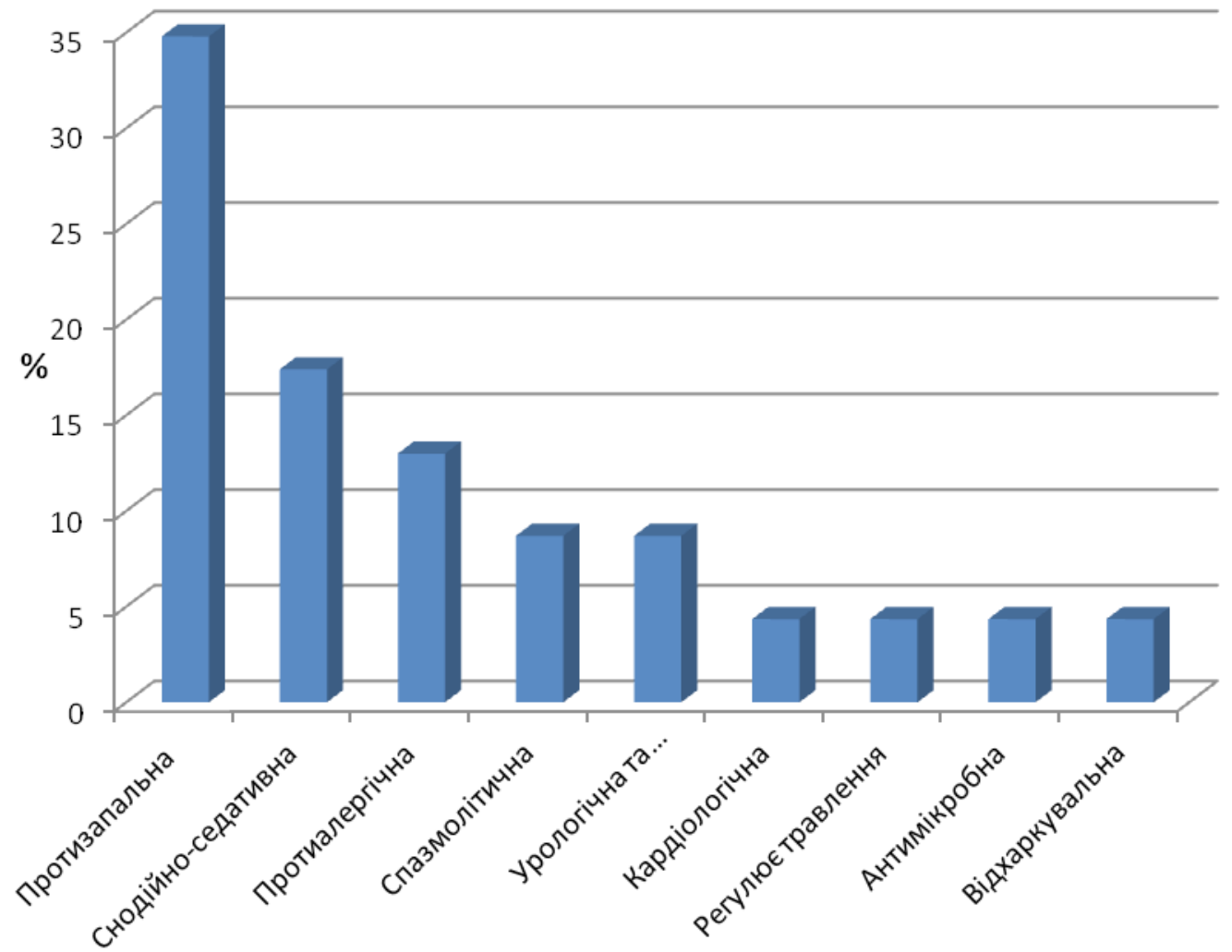

Рис. 1. Розподіл препаратів із вмістом бузини чорної за фрармакологічною дією.

Таблиця 1

Розподіл наявних на фрармацевтичному ринку України препаратів залежно від фрармакологічної дії

\begin{tabular}{|l|l|}
\hline \multicolumn{1}{|c|}{ Дія } & \multicolumn{1}{|c|}{ Препарати } \\
\hline Відхаркувальна & Бронхофріт \\
\hline $\begin{array}{l}\text { Протизапальна при захворюваннях } \\
\text { дихальних шляхів }\end{array}$ & $\begin{array}{l}\text { Бузини чорної квітки, Синупрет (краплі, таблетки, сироп), Синупрет } \\
\text { форте, Синупрет екстракт, Атма (краплі, таблетки) }\end{array}$ \\
\hline Снодійно-седативна & $\begin{array}{l}\text { Квайт, Ново-Пасит (таблетки, розчин оральний), Eкстракт } \\
\text { складний заспокійливий }\end{array}$ \\
\hline Урологічна та сечогінна & Нефррофріт, Урохолум \\
\hline $\begin{array}{l}\text { Кардіологічна, кардіотонічна, } \\
\text { антиаритмічна та гіпотензивна }\end{array}$ & Кардіофріт \\
\hline $\begin{array}{l}\text { Регулює функції травного тракту, } \\
\text { нормалізує моторику кишечника }\end{array}$ & Гастрофріт \\
\hline Антимікробна & Нефрофріт \\
\hline Спазмолітична & Нефррофіт, Гастрофріт \\
\hline Протиалергічна & Неінфрекційні алергени групи пилку росли, Атма (краплі, таблетки) \\
\hline
\end{tabular}

Серед препаратів іноземного виробника лідируючі позиції на українському ринку займають лікарські засоби, виготовленні в Німеччині (26,3 \%). Меншу частку в імпорті ліків до України мають Чехія і Австрія (по 10,5\%), а також Польща (5,3 \%) [6].

Першість за номенклатурою препаратів серед вітчизняних фрірм-виробників [6, 7] (рис. 4) належить ТОВ Науково-виробнича компанія «ЕЙМ», м. Харків
- 55,56 \%; тоді як на інші виробники, а саме: ПрАТ «Ліктрави», м. Житомир, ПАТ «Фармак», м. Київ, ТОВ «ДКП», м. Житомир та ТОВ «Імунолог», м. Вінниця, припадає по 11,11 \% від асортименту.

Ми проаналізували, які лікарські фрорми препаратів з Sambucus nigra на даний час зареєстровані на ринку України (рис. 5). Найбільше лікарських засобів представлено у вигляді таблеток - 26,4 \%, на другому

ISSN 2312-0967. Фармацевтичний часопис. 2019. № 2 
Фармацевтичний менеджмент, маркетинг та логістика

Pharmaceutical management, marketing and logistics

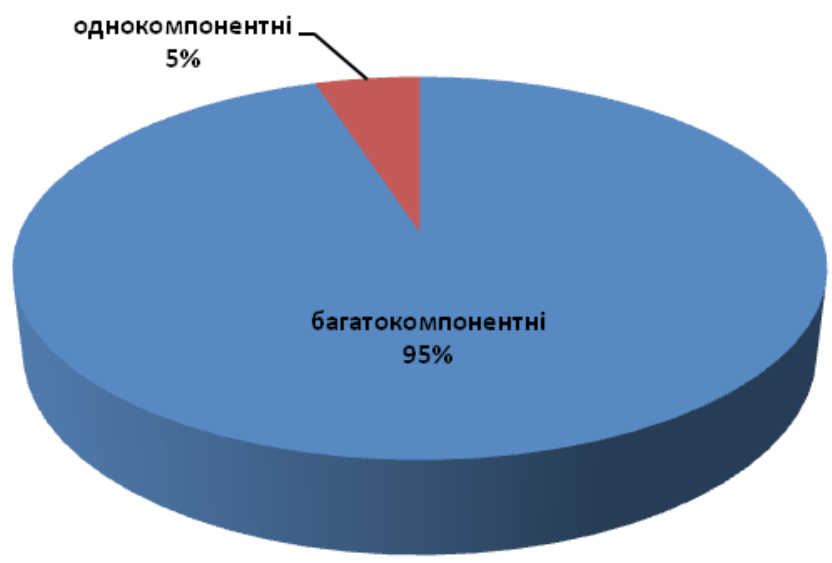

Рис. 2. Розподіл препаратів за кількісним складом.

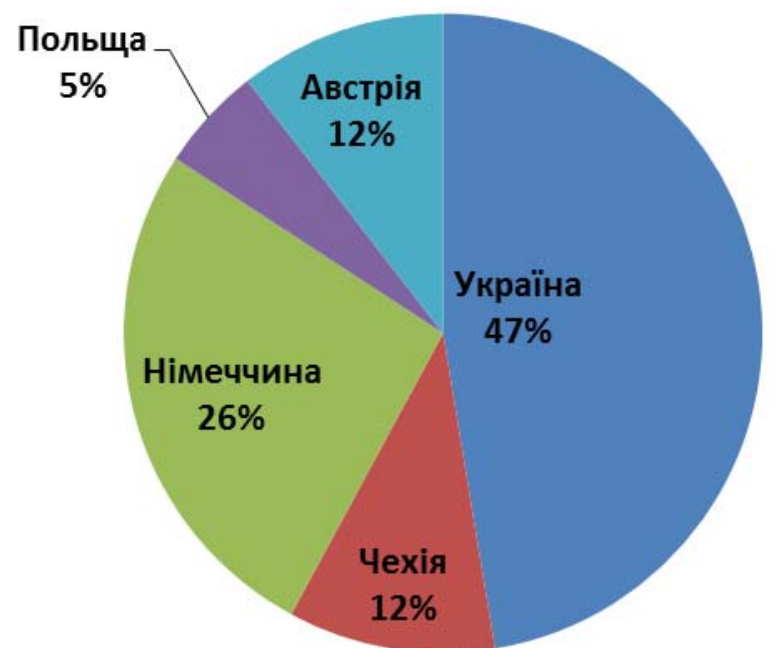

Рис. 3. Країни-виробники лікарських препаратів із вмістом Sambucus nigra, представлені на ринку України.

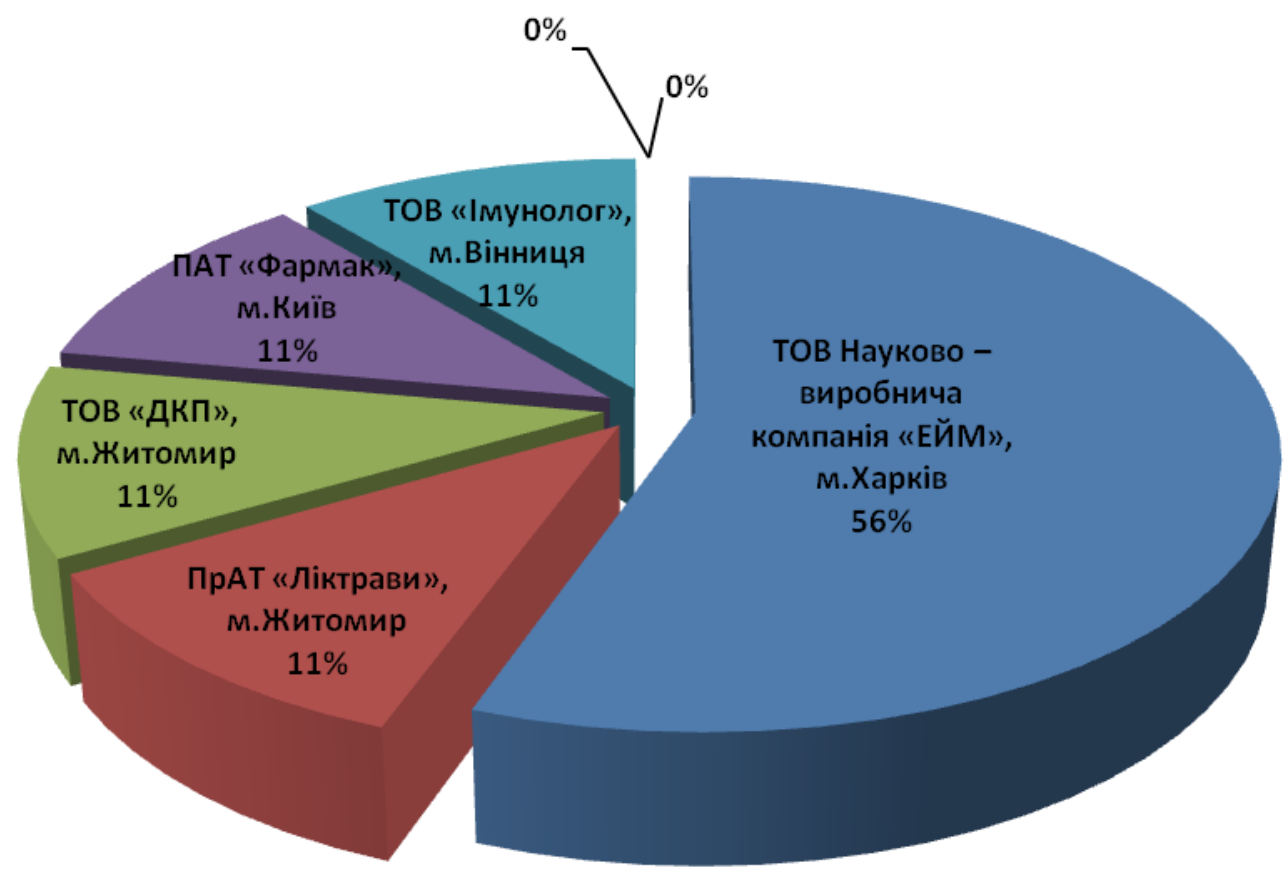

Рис. 4. Вітчизняні фрірми-виробники препаратів із вмістом Sambucus nigra.

ISSN 2312-0967. Pharmaceutical review. 2019. № 2 
Фармацевтичний менеджмент, маркетинг та логістика

Pharmaceutical management, marketing and logistics

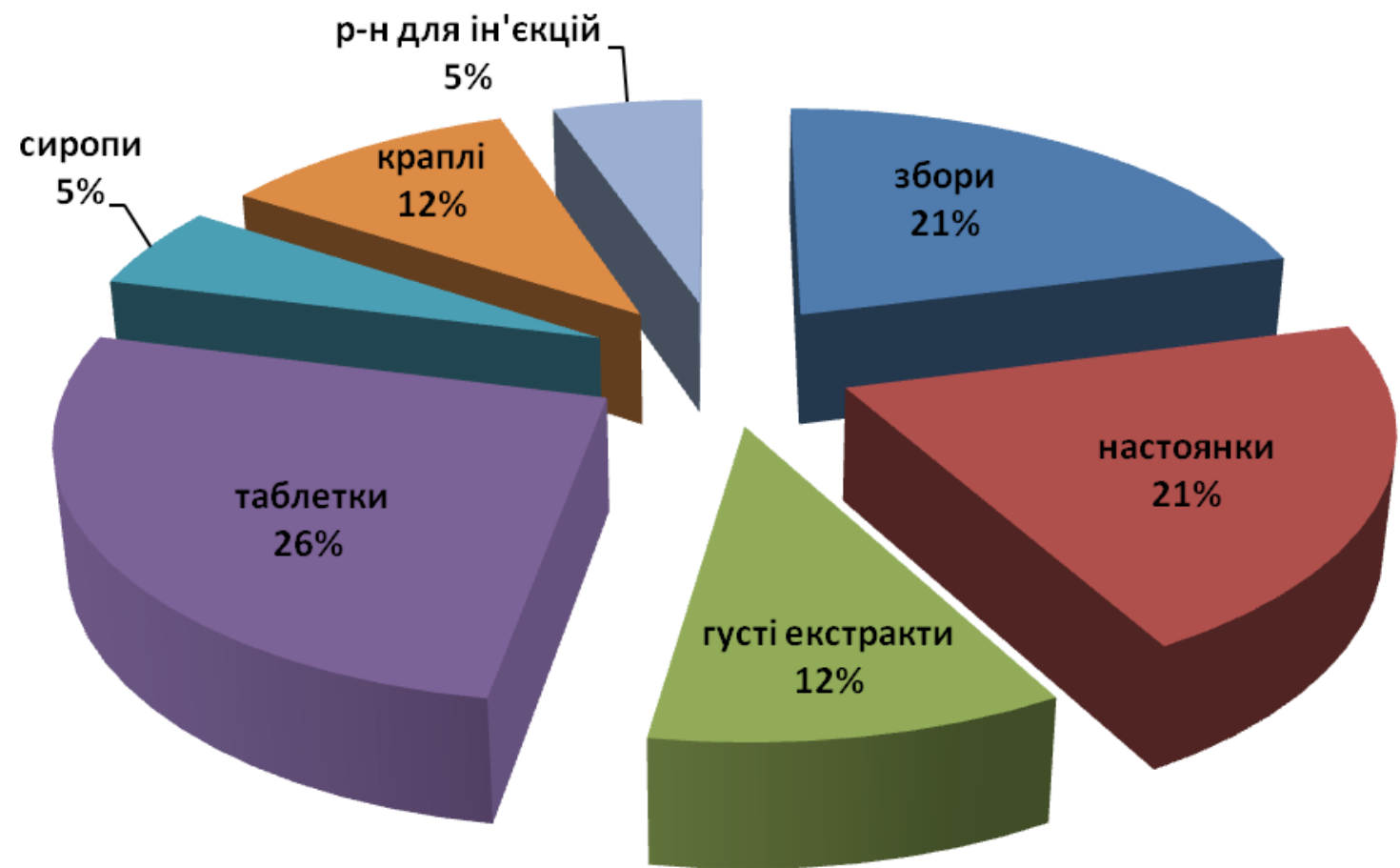

Рис. 5. Розподіл лікарських препаратів з вмістом Sambucus nigra за лікарською фрормою.

місці - настоянки та збори - їх частка по $21 \%$. У свою чергу, по 10,5 \% мають густі екстракти та краплі. Найменша частка належить сиропам та розчинам для ін'єкцій - по 5,3 \%, а зовсім не представлені спреї, пастилки та драже.
Проведені дослідження дали можливість скласти макроконтур цільового сегмента лікарських препаратів із вмістом Sambucus nigra на національному фрармацевтичному ринку (рис. 6).

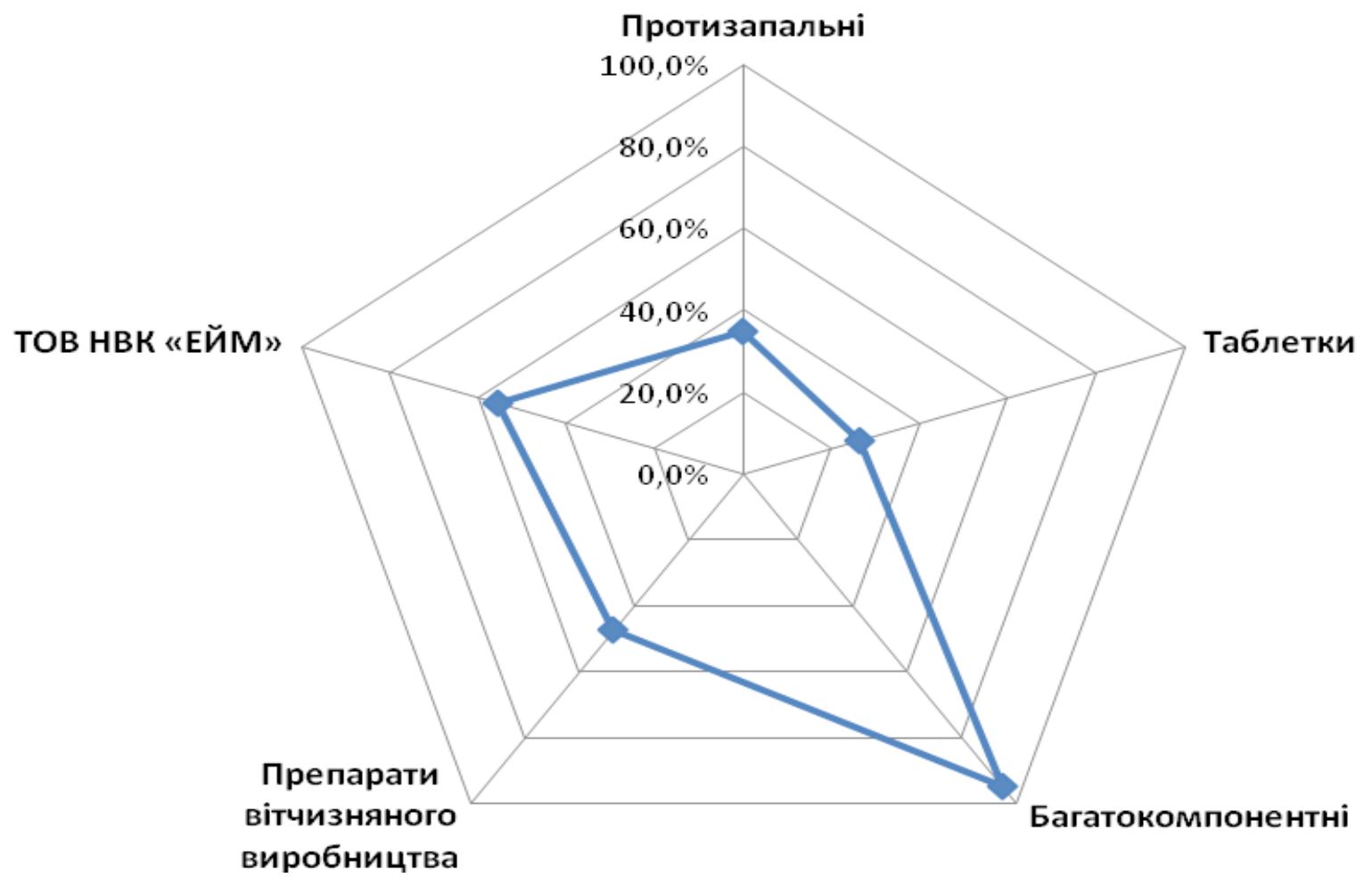

Рис. 6. Макроконтур фрармацевтичного ринку препаратів, до складу яких входить бузина чорна.

ISSN 2312-0967. Фармацевтичний часопис. 2019. № 2 
Фармацевтичний менеджмент, маркетинг та логістика

Pharmaceutical management, marketing and logistics

Проведені маркетингові дослідження та аналіз асортименту лікарських препаратів із вмістом Sambucus nigra, які зареєстровані на території України, дають можливість встановити:

1. Найбільше лікарських засобів зустрічається у вигляді таблеток (26,4 \%).

2. Переважаючу частку асортименту (95 \%) досліджених препаратів складають багатокомпонентні лікарські засоби.

3. Більшість препаратів із вмістом бузини чорної Sambucus nigra виготовлені на фрармацевтичних підприємствах України, серед яких лідером (55,56 \%) є ТОВ Науково-виробнича компанія «ЕЙМ», м. Харків.

4. Найчастіше лікарські препарати із вмістом бузини чорної - це протизапальні засоби.

5. Розробка нових сучасних оригінальних лікар- ських засобів на основі бузини чорної Sambucus nigra $€$ перспективною та конкурентоздатною на вітчизняному фрармацевтичному ринку.

Висновки. Проведений маркетинговий аналіз українського ринку лікарських та лікувально-профрілактичних препаратів показав, що хоча вітчизняних засобів на основі бузини чорної Sambucus nigra і найбільше, однак є широкі можливості щодо розширення асортименту та створення нових препаратів на основі даної рослинної сировини. Зокрема варто звернути увагу на найменш численні (сиропи та розчини для ін'єкцій) або взагалі не представлені фрорми (спреї, пастилки та драже).

Конфлікт інтересів: відсутній.

Conflicts of interest: authors have no conflict of interest to declare.

\title{
SAMBUCUS NIGRA В СОСТАВЕ ФАРМАЦЕВТИЧЕСКИХ ПРЕПАРАТОВ, ПРЕДСТАВЛЕННЫХ НА РЫНКЕ УКРАИНЫ
}

\author{
Н. Е. Стадницкая, О. М. Федоришин, А. О. Милянич, Х. И. Косаревич, В. П. Новиков \\ Национальный университет «Львовская политехника», Львов \\ nataliyastadnytska@gmail.com
}

Цель работы. Провести анализ ассортимента лекарственных препаратов, содержащих бузину черную Sambucus nigra, на современном срармацевтическом рынке Украины и определить целесообразность разработки новых препаратов на основании маркетингового исследования.

Материалы и методы. Анализ ассортимента перепаратов проводили согласно данным Государственного реестра лекарственных средств Украины (по состоянию на январь 2019 г.). Работа выполнена с использованием статистического, логического и грасического методов.

Результаты и обсуждение. Проведенные исследования показали, что большинство лекарственных средств представлены в виде таблеток (26,4 \%); преобладающую часть ассортимента (95 \%) исследованных препаратов составляют многокомпонентные лекарственные средства; большинство препаратов с содержанием бузины черной Sambucus nigra произведены на фрармацевтических предприятиях Украины, среди которых лидером (55,56 \%) является ООО Научно-производственная компания «ЭЙМ», г. Харьков; чаще всего лекарственные препараты с содержанием бузины черной - это противовоспалительные средства. Таким образом, полученные результаты указывают на то, что разработка новых современных оригинальных лекарственных средств на основе бузины черной Sambucus nigra является перспективной и конкурентоспособной на отечественном фрармацевтическом рынке.

Выводы. Проведенный маркетинговый анализ украинского рынка лекарственных и лечебно-профрилактических препаратов показал, что хотя доля отечественных средств на основе бузины черной Sambucus nigra и является крупнейшей, однако имеются широкие возможности по расширению ассортимента и созданию новых препаратов на основе данного растительного сырья. В частности стоит обратить внимание на самые малочисленные (сиропы и растворы для инъекций) или вообще не представлены формы (спреи, пастилки и драже).

Ключевые слова: бузина черная Sambucus nigra; маркетинговые исследования; фрармацевтический рынок Украины; фритопрепараты.

ISSN 2312-0967. Pharmaceutical review. 2019. № 2 
Фармацевтичний менеджмент, маркетинг та логістика

Pharmaceutical management, marketing and logistics

\title{
SAMBUCUS NIGRA IN THE COMPOSITION OF PHARMACEUTICAL PREPARATIONS REPRESENTED IN THE MARKET OF UKRAINE
}

\author{
N. Ye. Stadnytska, O. M. Fedoryshyn, A. O. Mylyanych, Kh. I. Kosarevych, V. P. Novikov \\ Lviv Polytechnic National University \\ nataliyastadnytska@gmail.com
}

The aim of the work. To conduct an analysis of the range of medicinal products containing elderberry black Sambucus nigra in the modern pharmaceutical market of Ukraine and determine the feasibility of developing new drugs based on marketing research.

Materials and Methods. The work is done using statistical, logical and graphical methods.

Results and Discussion. The conducted researches showed that the biggest part of drugs is found in the form of tablets (26.4\%); the predominant part of the assortment (95\%) of the studied drugs is multicomponent drugs; most of the preparations containing Ezine Black Sambucus nigra are produced at pharmaceutical enterprises of Ukraine, among which the Leader (55.56\%) is LLC Scientific-Production Company "EIM", Kharkiv; Mostly, medications containing elderberry black are anti-inflammatory drugs. Consequently, the results indicate that the development of new, up-to-date, original medicines based on elderberry Sambucus nigra is promising and competitive on the domestic pharmaceutical market.

Conclusions. The marketing analysis of the Ukrainian market for medical and prophylactic drugs has shown that although the share of home remedies based on the elderberry Sambucus nigra is the largest, however, there are wide opportunities for expanding the range and creating new drugs based on this plant material. In particular, it is worth paying attention to the least numerous (syrups and solutions for injection) or not presented forms (sprays, lozenges and dragees).

Key words: elderberry Sambucus nigra; marketing research; pharmaceutical market of Ukraine; phytopreparations.

\section{Список літератури}

1. Гудзенко А. В. Вітчизняний ринок багатокомпонентних лікарських засобів рослинного походження: аналіз стану структура та перспективи розвитку / А. В. Гудзенко, О. О. Цуркан, Т. В. Ковальчук // Фармацевтичний журнал. - 2012. - № 1. - С. 8-12.

2. Коваленко В. Н. Компендиум 2017 - Лекарственные препараты / За ред. В. Н. Коваленко. - К. : Морион, 2017. - 2224 с. (Електронний ресурс : https://compendium.com.ua/)

3. Чопик В. И. Дикорастущие полезные растения Украины : Справочник / В. И. Чопик, Л. Г. Дудченко, А. Н. Краснова. - Київ : Наукова думка, 1983. $400 \mathrm{c}$.

\section{References}

1. Hudzenko AV, Tsurkan OO, Kovalchuk TV. [Domestic market of multicomponent herbal medicinal products: analysis of the state of the structure and prospects of development]. Farmatsevtychnyi zhurnal. 2012;1: 8-12. Ukrainian.

2. Kovalenko VN. Compendium 2017 - Medicinal Products. [Компендиум 2017 - Лекарственные препараты] Kyiv: Morion; 2017. Available from: https://compendium. com.ual . Ukrainian.

3. Chopik VI, Dudchenko LG, Krasnova AN. Wild useful plants of Ukraine. Directory. [Дикорастущие полезные растения Украины. Справочник.] Kyiv: Naukova Dumka; 1983. Russian.

4. Hrodzinskyi AM. Medicinal plants: Encyclopedic Reference. [Лі́карські росли́ни: Енциклопеди́чний довідник]. Kyiv: Hol. red. URE; 1990. Ukrainian.
4. ГродзінськийА. М. Лі́карськіросли́ни:Енциклопеди́чний довідни́к / Відп. ред. А. М. Гродзінський. - К. : Гол. ред. УРЕ, 1990. - 544 с.

5. Про лікарські засоби : Закон України https ://rav.com.ua/ useful_know/norm_baza/zakon/law_medical_products/

6. https://tabletki.ua/category/257/

7. http ://www.drlz.com.ua/

8. Кархут В. В. Ліки навколо нас / В. В. Кархут. - К. : Здоров'я, 1975. - 448 с.

9. http ://www.bizslovo.org/content/index.php/ru/plavni/64rosl-svit/1074-buzyna-chorna.pdf

10. http ://ukmovlit.blogspot.com/2011/06/sambucus-nigra. $\mathrm{html}$

5. Law of Ukraine "On Medicines". Available from: https:// rav.com.ua/useful_know/norm_baza/zakon/law_medical_products/Ukrainian.

6. Search for medicines in pharmacies. Available from: https://tabletki.ua/category/257/ Russian.

7. State Register of Medicinal Substances of Ukraine. Available from: http://www.drlz.com.ua/ Ukrainian.

8. Karkhut VV. The medicine is around us. [Ліки навколо нас]. Kyiv: Zdorovia; 1975. Ukrainian.

9. Torop SO. Black elderberry (Sambukus nigra) [Бузина чорна (Sambukus nigra)] Available from: http://www. bizslovo.org/content/index.php/ru/plavni/64-roslsvit/1074-buzyna-chorna.pdf. Ukrainian.

10. The physician himself - the medicinal properties of plants and the treatment of herbs. Available from: http://ukmovlit. blogspot.com/2011/06/sambucus-nigra.html Ukrainian.

ISSN 2312-0967. Фармацевтичний часопис. 2019. № 2 
Фармацевтичний менеджмент, маркетинг та логістика Pharmaceutical management, marketing and logistics

\section{Відомості про авторів:}

Стадницька Н. Є. - канд. хім. н., доцент кафедри технології біологічно активних сполук, фрармації та біотехнології, Національний університет «Львівська політехніка», Львів, Україна. E-mail: nataliyastadnytska@gmail.com, ORCID 0000-0001-6261-0275

Федоришин О. М. - асист. кафедри технології біологічно активних сполук, фрармації та біотехнології, Національний університет «Львівська політехніка», Львів, Україна. E-mail: oljalvivua@gmail.com,ORCID 0000-0002-3113-8243

Милянич А. О. - канд. хім. н., доцент кафедри технології біологічно активних сполук, фрармації та біотехнології, Національний університет «Львівська політехніка», Львів, Україна. E-mail: Anri72@meta.ua, ORCID 0000-0002-61809925

Новіков В. П. - д. хім. н., професор, завідувач кафедри технології біологічно активних сполук, фрармації та біотехнології, Національний університет «Львівська політехніка», Львів, Україна. Email: vnovikov@polynet.lviv.ua, ORCID 0000-0002-0485-8720

Косаревич X. І. - студентка кафредри технології біологічно активних сполук, фрармації та біотехнології, Національний університет «Львівська політехніка», Львів, Україна.

\section{Information about authors:}

Stadnytska N. Y. - PhD (Chemistry), Associate Professor, Department of Technology of Biologically Active Substances, Pharmacy and Biotechnology Lviv Polytechnic National University, Lviv, Ukraine. ORCID 0000-0001-6261-0275

Fedoryshyn O. M. - Assistant of the Department of Technology of Biologically Active Substances, Pharmacy and Biotechnology, Lviv Polytechnic National University, Lviv, Ukraine ORCID 0000-0002-3113-8243

Mylyanych A. O. - PhD (Chemistry), Associate Professor, Department of Technology of Biologically Active Substances, Pharmacy and Biotechnology Lviv Polytechnic National University, Lviv, Ukraine. ORCID 0000-0002-6180-9925

Novikov V. P. - DSc (Chemistry), Professor, head of Department of Technology of Biologically Active Substances, Pharmacy and Biotechnology Lviv Polytechnic National University, Lviv, Ukraine. ORCID 0000-0002-0485-8720

Kosarevych X. I. - student of Technology of Biologically Active Substances, Pharmacy and Biotechnology Department, Lviv Polytechnic National University, Lviv, Ukraine. 